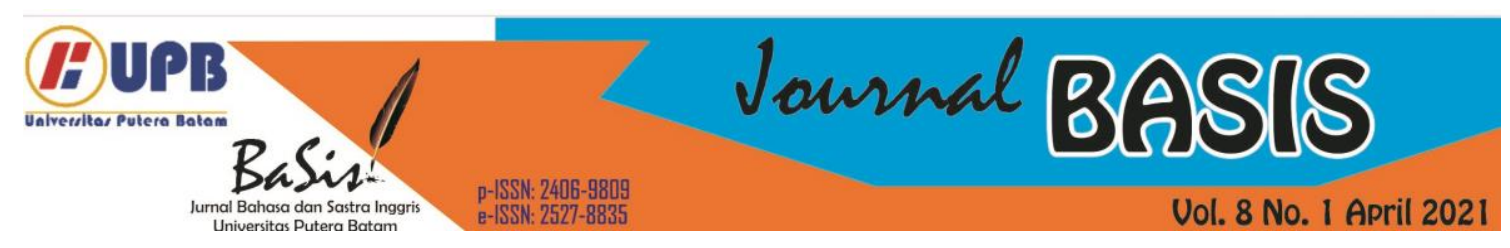

\title{
CODE SWITCHING USED BY PUBLIC FIGURES IN DEDDY CORBUZIER'S PODCAST: SOCIOLINGUISTICS APPROACH
}

\author{
Rika Fiorensera ${ }^{1}$ \\ Universitas Putera Batam (UPB), Batam, Indonesia \\ rikalim1404@gmail.com ${ }^{1}$ \\ Nurma Dhona Handayani ${ }^{2}$ \\ Universitas Putera Batam (UPB), Batam, Indonesia \\ nurmadhona@gmail.com ${ }^{2}$
}

\begin{abstract}
This research focused on the analysis of code switching used in conversations due to the presence of bilingual public figures that occur in Deddy Corbuzier's podcast. Researchers used a sociolinguistics approach and the objective of this research to describe the types of code-switching using in the Deddy Corbuzier podcast. There are three types such as tag switching, intersentential switching, and intrasentential switching. The data was analyzed by using Stockwell (2002) theory. The researchers used descriptive qualitative research methods to research by using theory of (Sudaryanto, 2015). This descriptive qualitative research was conducted by listening and analyzing the conversations videos as the data which then transcribed them in a written form. After analyzed some of the conversations in Deddy Corbuzier podcast the researcher was able to find some data related to the research and for the results of this research, researchers found 2 data related to the type of tag switching, 2 data related to the intersentential switching, and 5 data related to the intrasentential switching. The results showed that intra-sentential code switching was the type most frequently used.

Keywords: Bilingual, Code-Switching, Podcast, Sociolinguistics
\end{abstract}

\section{INTRODUCTION}

Humans talk and communicate with each other using language in everyday life. It is a communication tool to interact well with others. Humans interact with each other in many ways. One way to interact is through communication. This is very important for humans because it is the way humans build good relationships. Everyone has their way of starting communication. Many people tend to use language that they find easier for the other person to understand. In that way, people could be comfortable and connected in the conversation

Language skills in society could not be separated from social relationships between humans. The existence of a relationship between language and society is called sociolinguistics. According to Wardhaugh (2006), Sociolinguistics examines the relationship between language and society to achieve a deeper understanding of the structure of language and how language works in communication. The goal of sociolinguistics is to study every consequence that exists in the language used in society. It has been observed and traced that language and society are complementary. This means that society and language cannot be separated and interrelated. 
In communicating, people tend to use language that tends to be in the same frequency as the interlocutor so that it is easy to understand. According to Marlina (2017), it is not only with one language people communicate, but also more than one language with the abilities possessed by everyone. Besides that, the speaker must adjust the interlocutor in language use so that communication can occur clearly and connected. It often occurs in different languages. In this phenomenon, some people only speak one language which is called "monolingual", although many people can know more than one language even if only in a few words. People who have this ability are called "bilingual" and some people who can speak more than two languages are called "multilingual". This is the language skill of the people.

In sociolinguistics, one of the codes associated with bilingualism is codeswitching. According to Hoffman (1991), Code-switching is a language switch involving two languages in the same conversation. It is the use of other languages in one conversation to conform to other tasks or circumstances or because of the involvement of other participants. Code-switching happens, especially in bilingual societies. Speakers in more than one language are needed to switch code their language during a conversation.

Nowadays Indonesian people rarely use their mother tongue. They prefer to use Indonesian and learn more foreign languages. The language most often used and studied more by people is English. English can be used anywhere because English is an international language, therefore people want interaction and communication with each other often using two languages which are Indonesian and English. It can be reviewed and observed that nowadays these people tend to incorporate English and Indonesian codes in their daily communication.

In every city and region, the language is different from one another. However, most Indonesian citizens, especially in the Jakarta area, tend to use Indonesian and English more in their communication. The combination of these two languages then attracted attention because it was considered different from good and correct Indonesian. Some argue that the use of English in Indonesian is considered capable of elevating someone who uses it. Most children today do not apply their local language. People tend to prefer learning and applying foreign languages.

In that case, some people think code-switching is a good thing to implement. Most schools in Indonesia have implemented English as a compulsory language to learn in schools, especially international-based schools. English is very important in our lives today. This is why the ability to speak English is one of the main requirements to compete in the era of globalization. Language does not only act as a means of communication, it can also make it easier for you to adapt to your environment and work. But not only in schools, but many public figures in Indonesia also tend to use two languages in their daily life. Therefore, the researcher chose code-switching used in conversations by public figures in podcasts of Deddy Corbuzier.

\section{LITERATURE REVIEW \\ 2.1 Sociolinguistics}

Sociolinguistics is the philosophy that explores the usage of the language used by culture and language can evolve as a result of group interactions. Wardhaugh (2006) said sociolinguistics focuses on the relationship between language and society with the aim of better describing the purpose of language 
and how languages work in communication. The analysis deals with the language relationship and the sense in which it is used. It studies the connection between language and culture. It explains that in different social contexts we people speak differently Wardhaugh (2006) also said that people use language for day-to-day communication.

Sociolinguistics reflects mainly on the relationship between language and society therefore language is what certain members of the community speak. The language itself is a human tool to express thoughts and feelings. This also affects the way humans think of themselves. Humans as social beings can be characterized by the fact that they often wish to interact and communicate with other people from one culture or with people from different cultures. Someone that switches from one language to another is bilingual which can affect a variety of particular causes, such as settings or circumstances. Therefore sociolinguistics has a very important place in culture for human communication.

\subsection{Bilingual}

According to Marlina (2017), People who can speak two languages are called bilingual. Sociolinguistics is interested in the bilingual phenomenon. If bilingualism is defined as a syllable, bi- which means it has two, and lingua from Latin which means language. Bilingualism means "the use of two languages". Bilingualism is caused by the interaction of various language groups, the fluidity of the political and economic situation in many countries, and the rapid development of technology and telecommunications. To be able to use two languages, of course, one must master both languages. One of the bilingual countries is Indonesia. Their first language is their mother tongue, and their second language is the national language. This happens because Indonesia is a multicultural country with very diverse cultures and languages (Ameliza \& Ambalegin, 2020).

Bilingualism is regarding the use of bilingual languages such as regional and national languages in communicating to obtain a clear picture of information. By not changing the structure of the language and still following the existing context. Bilingualism is a term that combines the concept of bilingualism, as well as conditions that describe the occurrence of language communication between one language group and another language community. Bilinguals have many advantages, including being able to communicate in other languages, developing cooperation and understanding between communities, and increasing children's intelligence.

Kamariah (2019) add that the phenomenon of code switching nowadays is very often encountered in both direct and indirect communication or on social media. when doing doing the analysis based on of the types, researcher founds the reasons of using code switching there are four points: changing topic, lack of vocabulary, bilingual/multilingual, Prestige and trend.

\subsection{Code-Switching}

According to Wardhaugh (2006), code-switching refers to a phenomenon that language switch from one language to another language. Code-switching happens, especially in the bilingual environment. Speakers in more than one language are known for their ability to change code or combine their languages during the conversation. It is a way for people to communicate better and more productively with people who may not have the same language or cultural background. With code-switching, it is also necessary to be able to adapt to the 
group to convey thoughts and concepts that may be more easily explained in a particular language and regulate the strength of habit.

According to Palmer in Adi (2018) said that code-switching refers to the point where people switch between different languages in the same contact operation. This can be achieved while using a particular language in a different sentence as part of a conversation activity. But on the other hand, codeswitching has earned a bad reputation. It has been identified as a reason people lose their identity or accommodate prejudices against their ethnicity, religion, culture, and even social class. Hymes (1972) argues that the weaknesses of code-switching. They speak not according to the existing rules because they use two different languages. Those who code-switch are making a mess out of the conversation and are unable to speak the language properly.

\subsection{Types of Code Switching}

There are three types of code-switching according to Stockwell (2002), they are explained in detail as below:

\section{a. Tag Switching}

A tag switching is a type of codeswitching where in a sentence the language switches usually by using an interjection, a tag, statement that is located at the beginning or end of the sentence. This is the switching of either a single word or a tag phrase (or both) from one language to another. Simply insert a tag in one language in a phrase that is completely in the other language. It involves the insertion of a tag from one language into an utterance in another language. Typically, this kind of codeswitching is common in everyday conversations.

\section{b. Intersetential Switching}

Intersetential switching is a type of code-switching that occurs between sentences created by speakers. Generally, the focus of the topic may be modified by a pause used by one of the speakers. Pause is used as a brief interruption to signify a period of restriction or a term of the partnership. Intersetential switching to happen between more than one sentence. The alternation of a single discourse between two languages, where the switching takes place after the sentence in the first language has been finished and the next sentence begins with a new language. It exists between the border of the sentence where one clause or sentence is in one language and the next clause or sentence is in the other. Inter-sentential codeswitching takes place within the same sentence or between the speakers, which means that both languages are articulated in such a manner that the speaker can obey the laws of both languages.

\section{c. Intrasentential Switching}

Intrasentential Switching is switching from one language variety to another at the clause, phrase, or word level within a single utterance which is usually in the form of one word, phrase, or clause. Perhaps the most dynamic type of the three, because it can occur within the boundaries of a clause or sentence. Intra-sentential code-switching is a language alternation that happens within the boundary of a sentence or clause. Sometimes it involves mixing within the boundary of the term. Since intra-sentential code-switching happens within a sentence, clause, word boundary, or phrase.

\section{RESEARCH METHOD}

The research methodology aims to expand the techniques for researching solving problems in research. This section explains how research is conducted. Apart from that, this is also used as a guideline for conducting research and the theoretical methods 
used. Researchers used descriptive qualitative methods because of the data in the form of words, phrases, and sentences. The descriptive qualitative method is applied In this research. In this research, the researcher uses the object is about code-switching. The theory of code-switching is stated by (Wardhaugh, 2006). For the types of code-switching, it was stated by (Stockwell, 2002).

The code-switching was analyzed in the Deddy Corbuzier podcast. To collect data researchers used Sudaryanto (2015) method. According to Sudaryanto (2015), there are generally two methods to provide data: the listening method and the observation method. The listening method is done by listening to the use of language. The observation method is paralleled by the observational method in anthropological or social research. While the method of observation is done by observing the object of research. So in this research, the researchers use the listening method for collecting the data. The listening method is divided into four such as proficient listening technique, speech free listening technique, recording technique, and note-taking technique. In the proficient listening technique researchers only listen to the language used by the public figures, not the message or content of the conversation. In the speech free listening technique researchers only listen to the conversation of two or more people without any connection in the conversation. This technique is usually done when the research data is in written or document form. Meanwhile, after doing the above technique, the next step is the recording technique, this step is record all the conversations in the podcast for make it a transcript. Last is note-taking technique. The use of this note-taking technique is very flexible. Researchers can immediately taking note the data obtained.

\section{RESULT AND DISCUSSION}

\subsection{Result}

Based on the analyzed data, the researchers found data that was carried out as code-switching. From this data that has been found, the researcher classifies it based on types of codeswitching. There are three types of codeswitching such as tag switching, intersentential switching, and intrasentential switching. Based on the analysis, researchers found 2 data for tag switching, 2 data for intersentential switching, and 5 data for intrasentential switching. The data that has been found could be discussed in the discussion below.

\subsection{Discussion}

\section{Types of Code Switching \\ 1.1 Tag Switching}

Tag switching is typically used from another language or a different language that is inserted into the spoken language or language tags that are widely used by speakers and later converted to another language. The tag switching uses an interjection, tags, phrases.

\section{Data 1}

Agnez Mo : Yaaa gitu lah Ded...

Deddy : Gua punya pertanyaan pamungkas buat lo sebenarnya dan gua mau lu jawab sih sebenarnya pertanyaan pamungkas, kalo lu disuruh pilih untuk menjadi Warga Negara Indonesia atau mendapat green card di Amerika.

Agnez Mo : Oh by the way saya sudah di offered beberapa kali..

Deddy : green card untuk Warga Negara Amerika? (Corbuzier, 2019a) 
From the conversations carried out by the two public figures above, oh by the way saya sudah di offered beberapa kali.. This utterance contains tag switching. Because the word "by the way" is a phrase. The tag switching uses an interjection, tags, phrases, and is usually located at the beginning or end of a sentence while the word "by the way" is a phrase that is located in the first sentence, and does not change the main point of the sentence. Therefore, the above conversation is a type of tag switching.

Data 2

Reza : Dari sebelumnya sudah punya keluarga, trus dia punya gua keluarga lagi, gua gak ngerti man, dari gua kecil gua gak ngerti, sampai pernah diculik mungkin dia mau hak asuh, tapi hak asuh penuh ke nyok ap gua, culik culikan tarik tarikkan apa segala macam ,nyokap gua bawa kabur gua sampai ke Kalimantan, naik kapal sampan dikejar sama dia sama keluarganya, dikejar sampai dicari cari.

Deddy : Menurut lu apa itu hak asuh, adalah keputusan tepat sama nyokap lu? ..

Reza : Of course!, lihat gua sekarang, lihat gua sekarang mungkin kalau sama dia gua udah nembak orang, dengan sikap gua yang sombong ini mungkin gua udah todongin pistol ke kepala orang udah nabrakin orang ya mungkin ..

Deddy : Gimana itu caranya gua gak ngerti .. Rasanya orang yang tidak pernah lihat ayahnya sendiri , beda gak sih hidupnya. (Corbuzier, 2019b)

From the conversations carried out by the two public figures above, in the dialogue code-switching appears in the first sentence, namely the word "Of course!". The word "Of course!". is a category tag switching because the tag switching uses an interjection, tags, phrases, and is usually located at the beginning or end of a sentence while the word "Of course!" is an interjection that is located in the first sentence, and does not change the main point of the sentence. Therefore, the above conversation is a type of tag switching.

\subsection{Intersentential Switching}

Inter-sentential code-switching happens when a speaker interprets clauses in one language and then uses separate clauses in another language. Generally, the emphasis of the subject can be changed by a pause used by one of the speakers.

\section{Data 1}

Deddy : Tapi kalau lu tinggalnya diluar dan punya itu jadi kewajiban ya Juna : Ya jadi burden, beban banget (Corbuzier, 2020)

From the conversations carried out by the two public figures above, this utterance is a category of intersentential switching. Juna said "Ya jadi burden, beban banget" in this conversation Deddy paused in the conversation of the word "burden" after which he explained the word again in Indonesia "Beban". Therefore the sentences in the above conversation fall into the category of intersentential switching.

\section{Data 2}

Deddy : Well here I am three a.m, jam tiga pagi so I need to cut this down and I get to sleep 
Agnez Mo : Thank you so much thank you guys, everybody (Corbuzier, 2019a)

From the conversations carried out by the two public figures above, this utterance is a category of intersentential switching. Deddy said, "here I am three a.m, jam tiga pagi so I need to cut this down and I get to sleep" in this conversation Deddy paused in the conversation of the word "three a.m" after which he explained the word again in Indonesia "jam tiga pagi". Therefore the sentences in the above conversation fall into the category of intersentential switching.

\subsection{Intrasentential Switching}

Intra-sentential switching refers to switching that happens within the same clause or expression and then incorporates elements of both languages. Intra-sentential code-switching, shifting in the middle of a sentence, without interruptions, hesitations, or pauses signaling a switch.

\section{Data 1}

Agnez Mo : Yaaa gitu lah Ded...

Deddy : Gua punya pertanyaan pamungkas buat lo sebenarnya dan gua mau lu jawab sih sebenarnya

pertanyaan

pamungkas, kalo lu disuruh pilih untuk menjadi Warga Negara Indonesia atau mendapat green card di Amerika..

Agnez Mo : Oh by the way saya sudah di offered beberapa kali..

Deddy : Green card untuk Warga Negara Amerika? (Corbuzier, 2019a)

From the conversations carried out by the two public figures above, This utterance is a category of intrasentential switching. oh by the way saya sudah di offered beberapa kali. Agnez Mo added "offered" in the middle of the conversation. The verb "offered" here is a switch from the word "ditawarkan" in Indonesian to the English language. So that's why this is a category of intersentential switching from Indonesian to the English language.

Data 2

Agnez Mo : Contohnya gini misalnya Ded, em lu punya teman. .

Deddy : Oke....

Agnez : Teman lu uda tau lu orang Indonesia..

Deddy : emm. gak perlu nanya harusnya..

Agnez : gak perlu kasih tau gak perlu lagi eh eh gua orang indonesia mereka juga yeah i know you're indonesian, i know haha...(Corbuzier, 2019a)

From the conversations carried out by the two public figures above, This utterance is a category of intrasentential switching. the sentence "gua orang Indonesia" has the same expression as the sentence "yeah I know you're Indonesian" and this sentence is a clause. Here the subject is "I" the predicate "know" and the object phrase "you're Indonesian". In the first sentence, she uses Indonesian as the basic language. Then, in the next sentence, she uses English. So that's why this is a category of intersentential switching from Indonesian to the English language.

\section{Data 3}

Reza : Mungkin ada, ada ada ada kali ya ada keknya.

Deddy : Tapi lu tidak tau ?..

Reza : I don't know, emang kenapa kalau ada?.. 
Deddy : Gak ngaruh juga buat hidup lu sebenarnya... (Corbuzier, 2019b)

From the conversations carried out by the two public figures above, This utterance is a category of intrasentential switching. The sentence "I don't know" is a category of main clause/independent clause. In the first sentence, he uses English as the basic language. Then, in the next sentence, He uses Indonesian. So that's why this is a category of intersentential switching from English to the Indonesian language.

\section{Data 4}

Deddy : Dan dari itu semua kenapa lu bisa balik ke nyokap lu?..

Reza : Ya dewasa, sudah dewasa apa lagi yang harus diberantemin yaudahlah itu sudah terjadi gitu aja..

Deddy : Nyokap lu bangga gak sama lu sekarang?

Reza : Pastilah gila gak mungkin dia ga bangga, mungkin ditanya tahun 2016 dia masih bingung gua ngapain, like all my family .. No not all, most of my family, dari nyokap, ngira gua jualan narkoba karena gua banyak duit .. can you imagine that? Itu si Reza banyak duit karena jualan narkoba itu hati hati .. diomong gitu ke nyokap dan panik, ngocehin gua, karena dari 2015 - 2018 awal gua tidak pernah kasih tau gua ngapain aja.. (Corbuzier, 2019b)

From the conversations carried out by the two public figures above, This utterance is a category of intrasentential switching. From the sentence "Pastilah gila gak mungkin dia ga bangga, mungkin ditanya tahun 2016 dia masih bingung gua ngapain" after that Reza switch to English "like all my family .. No not all , most of my family," and he switch again "dari nyokap, ngira gua jualan narkoba karena gua banyak duit" then he added another English sentence "Can you imagine that"? after that he closed it with Indonesian "itu si reza banyak duit karena jualan narkoba itu hati hati .. Diomong gitu ke nyokap dan panik, ngocehin gua, karena dari 2015 - 2018 awal gua tidak pernah kasih tau gua ngapain aja.." is very clear that the speaker repeatedly switched languages. The conversation above has shifted in the middle of a sentence. So that's why this is a category of intersentential switching from English to the Indonesian language.

Data 5

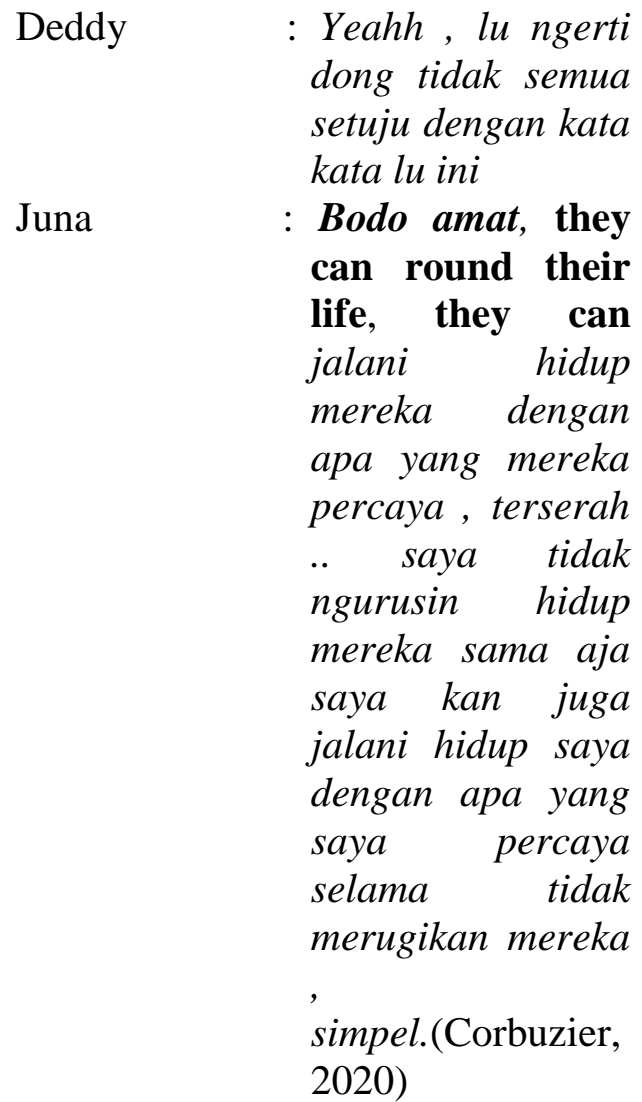

From the conversations carried out by the two public figures above, This utterance is a category of intrasentential switching. In the first sentence the 
speaker said "Bodo amat" after that the speaker switch to the English language "they can round their life, they can.. In the first sentence, he uses Indonesian as the basic language. Then, in the next sentence, He uses the English language in the middle. then the speaker repeated using the Indonesian language. The conversation above has shifted in the middle of a sentence. So that's why this is a category of intersentential switching from English to the Indonesian language.

\section{CONCLUSION}

From this analysis, the researcher concludes that code-switching occurs very often in Indonesia, especially in public figures. They could tend to use two languages at once rather than using only one language. Using two languages in everyday life is something that has become commonplace. Therefore, the researcher is interested in analyzing what types are included in code-switching. In code-switching, there are three types, namely: tag switching, intersentential switching, and intrasentential switching. These types are theory by (Stockwell, 2002). Researchers have researched and obtained some data from the results using qualitative descriptive methods stated by (Sudaryanto, 2015). Final result researchers conclude that the most types of code-switching used are intrasentential switching about 5 data, and second is tag switching about 3 data and the least is intersentential switching 1 data. Hopefully, this researcher can be of use to readers and future researchers who want to analyze the same topic.

\section{REFERENCES}

Adi, W. T. (2018). Code Switching in Critical Eleven Novel. Metathesis: Journal of English Language, Literature, and Teaching, 2(1), 39. https://doi.org/10.31002/metathesis. v2i1.514

Ameliza, T. C., \& Ambalegin, A. (2020). Code Switching Analysis in English Literature Whatsapp Group. Jurnal Basis, $\quad 7(1), \quad 141$. https://doi.org/10.33884/basisupb.v $7 \mathrm{i} 1.1837$

Corbuzier, D. (2019a). Agnez mo menjawab indonesia- exclusive! klarifikasi. Retrieved from 2019 website:

https://www.youtube.com/watch?v $=1 \mathrm{o} 4 \mathrm{hOpH} 54 \mathrm{Kk} \& \mathrm{t}=1496 \mathrm{~s}$

Corbuzier, D. (2019b). Reza arap, gue ga punya agama, ga punya bapak! Retrieved from 2019 website: https://www.youtube.com/watch?v $=\mathrm{B} 41 \mathrm{U} 4 \mathrm{SVqGjc} \& \mathrm{t}=598 \mathrm{~s}$

Corbuzier, D. (2020). Chef juna - g4y? jahanam? silakan!! $\square$. Retrieved from 2020 website: https://www.youtube.com/watch?v $=\mathrm{BGuFbCnd}-\mathrm{Xc} \& \mathrm{t}=38 \mathrm{~s}$

Hoffman, C. (1991). An introduction to bilingualism (1st ed.). London: Longman.

Hymes, D. (1972). Models for the interaction of language and social life BT - Directions in sociolinguistics: The ethnography of communications. In Directions in sociolinguistics: The ethnography of communications (pp. 35-71). Retrieved from papers2://publication/uuid/A1E395 64-C9D1-482B-90D0305DBC0B7763

Kamariah, Ambalegin. (2019). An Analysis Of Using Code Switching In Instagram. Jurnal Basis, [S.L.], V. 6, N. 2, P. 259-266, Oct. 2019. Issn 2527-8835. Available At: $<$ http://ejournal.upbatam.ac.id/inde x.php/basis/article/view/1431>

Marlina, L. (2017). Bilingualism and bilingual experiences: a case of two southeast asian female students at deakin university. Lingua 
Didaktika: Jurnal Bahasa Dan Pembelajaran Bahasa, 10(2), 182. https://doi.org/10.24036/ld.v10i2.74 29

Stockwell, P. (2007). Sociolinguistics: a resource Book for Students (2nd ed.). Newyork: Routledge.

Sudaryanto. (2015). Metode dan aneka teknik

analisis bahasa.Pengantarpenelitianwahanak ebudayaan secara linguistik. In Journal of Chemical Information and Modeling.

Wardhaugh, R. (2006). An introduction to sociolinguistics (5th ed.). Oxford: Blackwell. 